Zeszyty Naukowe Szkoły Głównej Gospodarstwa Wiejskiego w Warszawie

Problemy Rolnictwa Światowego tom 18 (XXXIII), zeszyt 1, 2018: 58-65

DOI: $10.22630 /$ PRS.2018.18.1.5

Agnieszka Huterska $^{1}$, Justyna Lapińska ${ }^{2}$, Ewa Zdunek-Rosa ${ }^{3}$

Uniwersytet Mikołaja Kopernika w Toruniu

\title{
Zasady wykorzystania środków z Programu Rozwoju Obszarów Wiejskich na lata 2014-2020 do termomodernizacji gospodarstw rolnych
}

\section{Rules of Using Rural Development Programme Funds for the Years 2014-2020 for Thermo-Modernisation of Agricultural Farms}

\begin{abstract}
Synopsis. Celem artykułu jest przedstawienie możliwego wsparcia gospodarstw rolnych w inwestycjach umożliwiających ich termomodernizację w ramach Programu Rozwoju Obszarów Wiejskich na lata 2014-2020. Główną metodą badawczą zastosowaną w pracy była analiza dostępnej literatury przedmiotu oraz aktów prawnych, zarówno unijnych, jak i krajowych regulujących poruszane w pracy zagadnienie. Przeprowadzono także porównanie liczby i wartości zakontraktowanych operacji oraz wartości zrealizowanych płatności w ramach PROW 2007-2013 i PROW 2014-2020. Analiza uregulowań prawnych pozwoliła na wskazanie możliwości wsparcia realizacji przedsięwzięć termomodernizacyjnych w gospodarstwach rolnych ze środków unijnych, natomiast analiza danych empirycznych pozwoliła ocenić oba programy pod kątem stopnia realizacji badanego działania na tle wszystkich działań dostępnych w ramach PROW.
\end{abstract}

Słowa kluczowe: gospodarstwo rolne, termomodernizacja, fundusze unijne

\begin{abstract}
The aim of the article is to present the possible support of agricultural farms in investments enabling their thermo-modernisation within the Rural Development Programme (PROW) for the years 2014-2020. The analysis of the available literature on the subject and legal acts, both ones of the European Union and national ones regulating the discussed issue, was chosen as a research method. A comparison was also made between the number and value of contracted operations and the value of payments made within PROW 2007-2013 and PROW 2014-2020. The analysis of the aforementioned legal acts allowed indicating the abilities to support the fulfilment of thermo-modernisation undertakings in agricultural farms from the EU funds, and the analysis of empirical data enabled an evaluation of both programmes in terms of the implementation rate of the activity when compared with all the activities available within PROW.
\end{abstract}

Key words: agricultural farm, thermo-modernisation, EU funds

JEL Classification: F02, O13, Q14

\footnotetext{
${ }^{1}$ dr, Wydział Nauk Ekonomicznych i Zarządzania UMK w Toruniu, ul. Gagarina 13a, 87-100 Toruń, e-mail: huterska@umk.pl

${ }^{2}$ dr hab., Wydział Nauk Ekonomicznych i Zarządzania UMK w Toruniu, ul. Gagarina 13a, 87-100 Toruń, e-mail: justlap@umk.pl

${ }^{3}$ dr, Wydział Nauk Ekonomicznych i Zarządzania UMK w Toruniu, ul. Gagarina 13a, 87-100 Toruń, e-mail: ezdunek@umk.pl
} 


\section{Wstęp}

Państwa członkowskie Unii Europejskiej - według wskazań Komisji Europejskiej zarówno na poziomie krajowym, jak i na poziomie unijnym powinny podjąć działania, zmierzające do zapewnienia bezpieczeństwa żywnościowego dla rosnącej populacji ludzi na świecie, prowadzenia zrównoważonej gospodarki zasobami naturalnymi, ograniczenia zależności od zasobów nieodnawialnych oraz łagodzenia zmian klimatycznych i przystosowania się do nich. Ograniczanie zależności od zasobów nieodnawialnych, takich jak węgiel, gaz, ropa naftowa ma sprzyjać ,,promocji UE jako gospodarki niskoemisyjnej i przyczyniać się do wzrostu produkcji ekologicznej” (Chyłek, 2012, s. 32). W powyższe wyzwania wpisuje się program biogospodarki oraz działania termomodernizacyjne.

Termomodernizacja budynku jest przedsięwzięciem zmierzającym do zmniejszenia zapotrzebowania i zużycia energii cieplnej w obiekcie budowlanym. Obejmuje ona zmiany w systemie ogrzewania i wentylacji, jak również zmiany w strukturze budynku oraz instalacjach doprowadzających ciepłą wodę. Do przedsięwzięć tego typu zalicza się nie tylko działania związane $\mathrm{z}$ modernizacją budynków mieszkalnych czy użyteczności publicznej (docieplanie przegród otaczających kubaturę ogrzewaną, wymiana okien i drzwi, wymiana starego sprzętu AGD, zastępowanie oświetlenia tradycyjnego oświetleniem ledowym czy montaż alternatywnych źródeł energii), ale również działania prowadzone w przedsiębiorstwach i gospodarstwach rolnych.

Celem artykułu jest przedstawienie możliwości wsparcia gospodarstw rolnych w inwestycjach umożliwiających ich termomodernizację, w ramach Programu Rozwoju Obszarów Wiejskich (PROW) na lata 2014-2020. Główną metodą badawczą jest analiza dostępnej literatury przedmiotu i aktów prawnych regulujących poruszane w pracy zagadnienie.

\section{Pojęcie termomodernizacji}

Według ustawy z dnia 21 listopada 2008 r. o wspieraniu termomodernizacji i remontów (Dz.U. 2008, art. 2 pkt 2) do przedsięwzięć termomodernizacyjnych zalicza się działania, w wyniku których następuje zmniejszenie zapotrzebowania na energię dostarczaną na potrzeby ogrzewania pomieszczeń i podgrzewania wody użytkowej, zmniejszenie strat energii pierwotnej w lokalnych sieciach ciepłowniczych oraz zasilających je lokalnych źródłach ciepła, wykonanie przyłącza technicznego do scentralizowanego źródła ciepła, w związku z likwidacją lokalnego źródła ciepła, w wyniku czego następuje zmniejszenie kosztów pozyskania ciepła oraz całkowita lub częściowa zamiana tradycyjnych źródeł energii na źródła odnawialne lub zastosowanie wysokosprawnej kogeneracji.

W Polsce program termomodernizacji budynków wprowadzono w roku 1999 na podstawie ustawy $\mathrm{z}$ dnia 18 grudnia 1998 r. o wspieraniu przedsięwzięć termomodernizacyjnych (Dz.U. 1998) ${ }^{4}$. Celem tego programu jest „zapewnienie technicznego i finansowego wsparcia projektów w zakresie oszczędności energii w budynkach oraz projektów dotyczących zmniejszania strat ciepła w sieciach dystrybucyjnych lub zastępowania tradycyjnych źródeł energii źródłami

\footnotetext{
${ }^{4}$ Ustawa ta utraciła moc prawną wraz z wejściem w życie ustawy z dnia 21 listopada 2008 r. o wspieraniu
} termomodernizacji i remontów (Dz. U. 2008). 
niekonwencjonalnymi, w tym odnawialnymi” (Efektywność energetyczna). Czesść środków na termomodernizację można uzyskać z Funduszu Termomodernizacji i Remontów ${ }^{5}$. W latach 1999-2015 fundusz ten zasilono kwotą nieco ponad 2 mld zł (BGK).

\section{Definicja gospodarstwa rolnego}

$\mathrm{W}$ artykule omówione zostanie wsparcie gospodarstw rolnych $\mathrm{w}$ inwestycjach umożliwiających ich termomodernizację $w$ ramach Programu Rozwoju Obszarów Wiejskich na lata 2014-2020. W związku z tym zasadne jest podanie definicji gospodarstwa rolnego. $\mathrm{W}$ pracy posłużono się cywilistycznym podejściem do omawianego zagadnienia. Zgodnie z artykułem 55[3] ustawy z dnia 23 kwietnia 1964 r. Kodeks cywilny (Dz.U. 2016) za gospodarstwo rolne uważa się grunty rolne wraz $\mathrm{z}$ gruntami leśnymi, budynkami lub ich częściami, urządzeniami i inwentarzem, jeżeli stanowią lub mogą stanowić zorganizowaną całość gospodarczą, oraz prawami związanymi z prowadzeniem gospodarstwa rolnego. Zgodnie z postanowieniem Sądu Najwyższego z dnia 14 maja 2002 roku - Izba Cywilna w sprawie IV CKN 1023/00 powołującym się także na zawartą w artykule 41[1] Ustawy Kodeks Cywilny (Dz.U. 2016) definicję nieruchomości rolnej składniki majątku możemy określić jako gospodarstwo rolne, jeżeli nie tylko stanowią, ale także mogą stanowić zorganizowaną całość gospodarczą. Potwierdza to także postanowienie Sądu Najwyższego z dnia 7 maja 1997 roku - Izba Cywilna w sprawie II CKN 137/97 zgodnie z którym wymienione w art. 55[3] KC (Dz.U. 2016) przedmioty wraz $\mathrm{z}$ prawami i obowiązkami związanymi $\mathrm{z}$ prowadzeniem gospodarstwa rolnego, są gospodarstwem rolnym nie tylko wtedy, gdy stanowią zorganizowaną całość gospodarczą, ale również wówczas, gdy potencjalnie mogą ją stanowić. W sensie przedmiotowym najistotniejszym składnikiem gospodarstwa rolnego jest grunt rolny (postanowienie Sądu Najwyższego z dnia 7 maja 1997 roku - Izba Cywilna w sprawie II CKN 137/97), niemniej związanie gospodarstwa rolnego z zabudową zagrodową należy rozumieć funkcjonalnie, przyjmując cywilistyczne rozumienie gospodarstwa jako pewnej całości produkcyjnej (Wyrok Wojewódzkiego Sądu Administracyjnego z dnia 14 listopada 2012 roku w sprawie II SA/Sz 866/12). Z powyższego wynika także konieczność zaliczenia budynków mieszkalnych w skład gospodarstwa rolnego (Wyrok Wojewódzkiego Sądu Administracyjnego z dnia 14 listopada 2012 roku w sprawie II SA/Sz 866/12).

\section{Funkcjonowanie gospodarstw rolnych a koncepcja zrównoważonego rozwoju}

Funkcjonowanie nowoczesnych gospodarstw rolnych wiąże się ściśle z rosnącym zapotrzebowaniem na energię, $w$ tym przede wszystkim na energię elektryczną. W związku z rosnącymi cenami paliw i energii elektrycznej, rolnicy muszą z jednej strony racjonalnie gospodarować energią, z drugiej natomiast poszukiwać innych jej źródeł.

\footnotetext{
${ }^{5}$ Środki te przyznaje Bank Gospodarstwa Krajowego z Funduszu Termomodernizacji i Remontów. Inwestorzy mogą otrzymać $20 \%$ zwrotu kwoty kredytu zaciągniętego na realizację przedsięwzięcia termomodernizacyjnego. Jest to tzw. premia termomodernizacyjna (art. 3 i 5 ustawy o wspieraniu modernizacji i remontów, Dz.U. 2008).
} 
Programy Unii Europejskiej oraz strategie rządowe promują koncepcję zrównoważonego rozwoju, polegającą m.in. na wykorzystywaniu odnawialnych źródeł energii. „Zrównoważone rolnictwo” polega na realizacji produkcji rolnej - uwzględniając potrzebę ochrony środowiska i ograniczonych zasobów naturalnych - przy wykorzystaniu potencjału, jaki niesie ze sobą postęp techniczny (Gospodarz z energią; Żmija, 2014). Model zrównoważonego rolnictwa może być realizowany np. przez racjonalną eksploatację surowców z gospodarstwa, jak również wykorzystywanie odpadów rolniczych do wytwarzania energii czy nawozów.

Do alternatywnych źródeł energii w rolnictwie można zaliczyć m.in. następujące technologie wykorzystujące odnawialne źródła energii: kolektory słoneczne, ogniwa fotowoltaiczne (panele PV), mikrobiogazownie, kotły na biomasę, małe turbiny wiatrowe, małe elektrownie wodne (Gospodarz z energia). Zastosowanie powyższych rozwiązań w gospodarstwach rolnych pociaga za sobą zarówno korzyści finansowe, jak i ekologiczne. Następuje zmniejszenie ilości i kosztów zakupu energii z zewnątrz. Ponadto wytwarzanie energii ze źródeł odnawialnych charakteryzuje się zerową lub co najwyżej niewielką emisją zanieczyszczeń.

Dyrektywy Parlamentu Europejskiego i Rady nakazują ponadto konieczność racjonalnego gospodarowania energią. Poprawa efektywności energetycznej pozwala bowiem ograniczyć emisję gazów cieplarnianych oraz zapewnić trwałe dostawy energii.

W gospodarstwach rolnych energię ekologiczną można otrzymywać wykorzystując różne odnawialne źródła energii. Możliwe jest wykorzystanie nadwyżki słomy (biomasa) pod warunkiem, że jej wilgotność nie przekroczy $25 \%$ i do jej spalania są wykorzystywane odpowiednie kotły. W gospodarstwie rolnym na glebach słabych, zdegradowanych możliwa jest uprawa roślin energetycznych, takich jak topola, wierzba, miskant. Biomasa drzewna, uzyskana z przecinki własnego lasu, może służyć jako podpałka i dodatek do węgla. Istnieje też możliwość wykorzystania produktów ubocznych z rolnictwa - biogaz otrzymywany z obornika - poprzez budowę mikrobiogazowni, oraz wykorzystanie energii słonecznej poprzez montaż kolektorów słonecznych do podgrzewania ciepłej wody jako alternatywa dla bojlera elektrycznego.

Wszystkie wymienione powyżej działania wymagają jednak poniesienia przez gospodarstwo rolne nakładów finansowych, umożliwiających realizację zaplanowanej inwestycji. Istnieją jednakże programy, dzięki którym możliwe jest uzyskanie dofinansowania do części kosztów związanych $\mathrm{z}$ inwestycjami umożliwiającymi termomodernizację.

\section{Zasady udzielania pomocy w ramach Programu Rozwoju Obszarów Wiejskich na lata 2014-2020}

Program Rozwoju Obszarów Wiejskich na lata 2014-2020 (PROW 2014-2020) został opracowany na podstawie przepisów Unii Europejskiej, takich jak rozporządzenie Parlamentu Europejskiego i Rady (UE) nr 1305/2013 z dnia 17 grudnia 2013 r. w sprawie wsparcia rozwoju obszarów wiejskich przez Europejski Fundusz Rolny na rzecz Rozwoju Obszarów Wiejskich (EFRROW) i uchylającego rozporządzenie Rady (WE) nr 1698/2005 oraz aktów delegowanych i wykonawczych Komisji Europejskiej (Ustawa z dnia 20 lutego 2015). Ratio legis rozporządzenia ma na celu wykonanie upoważnienia zawartego w art. 45 ust. 1 ustawy z dnia 20 lutego 2015 o wspieraniu rozwoju obszarów wiejskich z udziałem 
środków EFRROW w Ramach PROW na lata 2014-2020 (Uzasadnienie Projektu Rozporządzenia).

Program realizuje sześć celów wyznaczonych dla unijnej polityki rozwoju obszarów wiejskich na lata 2014-2020, do których należą (Ustawa z dnia 20 lutego 2015):

1) ułatwianie transferu wiedzy i innowacji w rolnictwie, leśnictwie i na obszarach wiejskich;

2) poprawa konkurencyjności wszystkich rodzajów gospodarki rolnej i zwiększenie rentowności gospodarstw rolnych;

3) poprawa organizacji łańcucha żywnościowego i promowanie zarządzania ryzykiem w rolnictwie;

4) odtwarzanie, chronienie i wzmacnianie ekosystemów zależnych od rolnictwa i leśnictwa;

5) wspieranie efektywnego gospodarowania zasobami i przechodzenia na gospodarkę niskoemisyjną i odporną na zmianę klimatu w sektorach: rolnym, spożywczym i leśnym;

6) zwiększanie włączenia społecznego, ograniczanie ubóstwa i promowanie rozwoju gospodarczego na obszarach wiejskich.

Cel piąty może być osiagnięty $\mathrm{w}$ ramach operacji „Modernizacja gospodarstw rolnych”, w ramach której realizowane jest poddziałanie „Wsparcie inwestycji w gospodarstwach rolnych".

Z PROW na lata 2014-2020 możliwe jest uzyskanie wsparcia na modernizację gospodarstw rolnych w ramach poddziałania 4.1 „Wsparcie inwestycji w gospodarstwach rolnych". Szczegółowe zasady przyznawania pomocy reguluje Rozporządzenie Ministra Rolnictwa i Rozwoju Wsi w sprawie szczegółowych warunków i trybu przyznawania oraz wypłaty pomocy finansowej na operacje typu "Modernizacja gospodarstw rolnych" w ramach poddziałania „Wsparcie inwestycji w gospodarstwach rolnych” objętego Programem Rozwoju Obszarów Wiejskich na lata 2014-2020 z dnia 21 sierpnia 2015 r. (Dz.U. 2015) uchwalone na podstawie art. 45 ust. 1 pkt 1 ustawy z dnia 20 lutego 2015 r. o wspieraniu rozwoju obszarów wiejskich $\mathrm{z}$ udziałem środków EFRROW $\mathrm{w}$ ramach PROW na lata 2014-2020 (Dz.U. 2015).

Ze środków unijnych możliwe jest uzyskanie pomocy na materialne i niematerialne inwestycje, które przyczynią się do poprawy ogólnej wydajności gospodarstwa rolnego, przez którą rozumie się poprawę konkurencyjności i zwiększenie rentowności gospodarstwa rolnego w wyniku jego restrukturyzacji. Poprawa ogólnych wyników gospodarstwa rolnego może polegać między innymi na poprawie efektywności wykorzystania energii w gospodarstwie i zwiększeniu wykorzystania w nim odnawialnych źródeł energii. Wykorzystanie tychże źródeł musi zostać jednak uzasadnione ekonomicznie (PROW, s. 231). Pomoc polega na refundacji części kosztów kwalifikowanych inwestycji i jest skierowana do rolnika lub grupy rolników, którzy prowadzą działalność rolniczą w celach zarobkowych (PROW, s. 232), co wskazane jest w paragrafie 7 rozporządzenia Ministra Rolnictwa i Rozwoju Wsi w sprawie szczegółowych warunków i trybu przyznawania oraz wypłaty pomocy finansowej na operacje typu „Modernizacja gospodarstw rolnych” w ramach poddziałania „Wsparcie inwestycji w gospodarstwach rolnych" objętego PROW na lata 2014-2020 z dnia 21 sierpnia 2015 r. (Dz.U. 2015).

Do kosztów kwalifikowanych, które muszą być bezpośrednio związane z działalnością rolniczą, zaliczamy koszty budowy lub modernizacji budynków lub budowli, koszty zakupu i instalacji lub leasingu, zakończonego przeniesieniem prawa własności, nowych maszyn i wyposażenia do wartości rynkowej majątku; koszty zakupu i instalacji lub budowy elementów infrastruktury technicznej (PROW, s. 233), co wskazane jest w paragrafie 9 punkcie 1 ustęp 6 przepisów krajowych. 
Zgodnie z PROW pomoc nie jest skierowana do rolników, których gospodarstwo rolne ma powierzchnię przewyższająca 300 ha (PROW, s. 234) - co wskazane jest w paragrafie 2 ustęp 1 punkcie 1a przepisów krajowych.

Tabela 1. Poziom realizacji PROW 2014-2020 na dzień 31.12.2016 r. dla działania „Modernizacja gospodarstw rolnych"

Table 1. The rate of PROW 2014-2020 implementation as on the 31st December 2016 action "Modernisation of Agricultural Farms"

\begin{tabular}{|c|c|c|c|}
\hline $\begin{array}{l}\text { Program Rozwoju Obszarów Wiejskich } \\
\text { 2014-2020 }\end{array}$ & $\begin{array}{c}\text { Liczba zawartych } \\
\text { umów/wydanych } \\
\text { decyzji }\end{array}$ & $\begin{array}{c}\text { Kwota zawartych } \\
\text { umów/wydanych } \\
\text { decyzji (w zl) }\end{array}$ & $\begin{array}{l}\text { Kwota } \\
\text { zrealizowanych } \\
\text { płatności (w zł) }\end{array}$ \\
\hline $\begin{array}{l}\text { Działanie: „Modernizacja gospodarstw } \\
\text { rolnych” (do 31.12.2016) }\end{array}$ & 2827 & 711696237 & 10425600 \\
\hline $\begin{array}{l}\text { Udział \% działania „Modernizacja } \\
\text { gospodarstw rolnych” w działaniach ogółem } \\
\text { PROW 2014-2020 (do 31.12.2016) }\end{array}$ & $0,20 \%$ & $5,60 \%$ & $0,21 \%$ \\
\hline
\end{tabular}

Źródło: (MRiRW. Monitoring i sprawozdawczość PROW 2014-2020), opracowanie własne.

Projekty, które wpływają na zwiększenie wykorzystywania odnawialnych źródeł energii w gospodarstwie są zaliczone do tych działań, dla których przewidziano preferencje w przyznawaniu pomocy (PROW, s. 235). Ze środków unijnych dofinansowaniu podlega $60 \%$ kosztów kwalifikowalnych operacji w przypadku młodych rolników i inwestycji zbiorowych lub 50\% kosztów kwalifikowalnych w przypadku pozostałych operacji, przy czym maksymalna kwota pomocy wynosi $900000 \mathrm{zl}$ w przypadku realizacji celu rozwój produkcji prosiąt i $500000 \mathrm{zł} \mathrm{w}$ przypadku pozostałych celów. Pomoc zostaje przyznana przy planowanej wysokości kosztów kwalifikowanych powyżej 50000 zł (PROW, s. 235). Przepisy krajowe określają powyższe limity w paragrafach 7 ustęp 4 punkt 1 i 2 oraz paragrafie 8 ustęp 1 i 2 Rozporządzenia (Dz.U. 2015).

Tabela 2. Poziom realizacji PROW 2007-2013 na dzień 31.12.2015 r. oraz na dzień 31.12.2009 r. dla działania „Modernizacja gospodarstw rolnych"

Table 2. The rate of PROW 2007-2013 implementation as on the 31st December 2015 and 31st December 2009 action "Modernisation of Agricultural Farms"

\begin{tabular}{|c|c|c|c|}
\hline $\begin{array}{l}\text { Program Rozwoju Obszarów Wiejskich } \\
\text { 2007-2013 }\end{array}$ & $\begin{array}{l}\text { Liczba zawartych } \\
\text { umów/wydanych } \\
\text { decyzji }\end{array}$ & $\begin{array}{l}\text { Kwota zawartych } \\
\text { umów/wydanych } \\
\text { decyzji (w zł) }\end{array}$ & $\begin{array}{l}\text { Kwota } \\
\text { zrealizowanych } \\
\text { płatności (w zł) }\end{array}$ \\
\hline $\begin{array}{l}\text { Działanie: „Modernizacja gospodarstw } \\
\text { rolnych” (do 31.12.2015) }\end{array}$ & 73112 & 10393341949 & 10219057662 \\
\hline $\begin{array}{l}\text { Działanie: „Modernizacja gospodarstw } \\
\text { rolnych” (do 31.12.2009) }\end{array}$ & 23207 & 3032977309 & 1478516310 \\
\hline $\begin{array}{l}\text { Udział \% działania „Modernizacja } \\
\text { gospodarstw rolnych” w działaniach ogółem } \\
\text { PROW 2007-2013 (do 31.12.2009) }\end{array}$ & $0,98 \%$ & $20,32 \%$ & $13,00 \%$ \\
\hline
\end{tabular}

Źródło: (MRiRW. Monitoring i sprawozdawczość PROW 2007-2013), opracowanie własne.

Planowane łączne środki publiczne przeznaczone na realizację PROW 2014-2020 wynoszą 13513295000 euro, w tym: z Europejskiego Funduszu Rolnego na rzecz Rozwoju Obszarów Wiejskich (EFRROW) przeznaczone jest 8598280814 euro (tj. 63,6\%), a z budżetu krajowego 4915014186 euro (tj. 36,4\%) (Ustawa z dnia 20 lutego 2015). 
Do dnia 31 grudnia 2016 r. ogółem w ramach PROW 2014-2020 zostały złożone 1751353 wnioski o przyznanie pomocy finansowej. Do realizacji zatwierdzono 1391330 operacji. Do dnia 31 grudnia 2016 r. zakontraktowano nieco ponad 21\% budżetu PROW 2014-2020. Do końca 2016 r. zostały zrealizowane płatności w kwocie 4988427518 zł (1 153176494 euro). Stanowi to ponad 8\% budżetu PROW 2014-2020. Z wypłat skorzystało 852729 beneficjentów (MRiRW. Monitoring i sprawozdawczość PROW 2014-2020).

W tabeli 1 przedstawiono stan realizacji PROW 2014-2020 za pierwsze trzy lata funkcjonowania programu, tj. od 01.01.2014 r. do 31.12.2016 r. dla działania „Modernizacja gospodarstw rolnych". W ramach tego działania, jak wcześniej wspomniano, jest w głównej mierze realizowany priorytet 5 PROW 2014-2020, uwzględniający m.in. efektywność energetyczną gospodarstw rolnych i wykorzystywanie odnawialnych źródeł energii.

Dla porównania, w tabeli 2 przedstawiono stan realizacji PROW 2007-2013 za cały okres funkcjonowania programu oraz za pierwsze trzy lata funkcjonowania programu, $\mathrm{tj}$. od 01.01.2007 r. do 31.12.2009 r. dla działania „Modernizacja gospodarstw rolnych”.

Porównując oba programy dla pierwszych trzech lat ich funkcjonowania (w ramach działania „Modernizacja gospodarstw rolnych”) można stwierdzić, że liczba zawartych umów/wydanych decyzji na koniec 2016 r. była aż o ok. 88\% niższa niż na koniec roku 2009. Wartość zawartych umów/wydanych decyzji do dnia 31.12.2016 r. była natomiast niższa o prawie $77 \% \mathrm{w}$ stosunku do kwoty zawartych umów/wydanych decyzji do dnia 31.12.2009 r. Kwota zrealizowanych płatności w analizowanym okresie w ramach PROW 2014-2020 była aż o 99\% niższa niż w ramach PROW 2007-2013.

\section{Podsumowanie}

Prowadzenie zrównoważonej gospodarki zasobami naturalnymi oraz ograniczanie zależności od zasobów nieodnawialnych należy do celów, do których mają dążyć państwa Unii Europejskiej, zarówno na szczeblu krajowym, jak i na poziomie unijnym. Działania termomodernizacyjne prowadzone $\mathrm{w}$ gospodarstwach rolnych - zmierzające zarówno do zmniejszenia zużycia energii, jak i zastępowania tradycyjnych źródeł energii odnawialnymi wpisują się w koncepcję zrównoważonego rozwoju, w przypadku gospodarstw rolnych polegającą między innymi na realizacji produkcji rolnej w sposób uwzględniający potrzebę ochrony środowiska i ograniczonych zasobów naturalnych. W artykule wskazano na możliwość realizacji przedsięwzięć termomodernizacyjnych w ramach poddziałania 4.1,Wsparcie inwestycji w gospodarstwach rolnych" realizowanego z Programu Rozwoju Obszarów Wiejskich na lata 2014-2020. W ramach tego poddziałania realizowanych może być szereg innych inwestycji w gospodarstwach rolnych służących ochronie środowiska lub zapobieganiu zmianie klimatu. Do takich inwestycji zalicza się $\mathrm{m}$. in. inwestycje związane z produkcją zwierzęca, zakup maszyn do uprawy gleby, zakup opryskiwaczy do stosowania środków ochrony roślin itp. (Załącznik do rozporządzenia MRiRW).

W opracowaniu podjęto próbę odniesienia stanu realizacji działania „Modernizacja gospodarstw rolnych" do stanu realizacji wszystkich działań objętych PROW. W ciagu pierwszych trzech lat funkcjonowania obu programów dla działania „Modernizacja gospodarstw rolnych" można zauważyć, że w ramach PROW 2014-2020 zakontraktowano relatywnie mniej operacji niż w ramach PROW 2007-2013. Podobna sytuacja występuje w przypadku wartości zakontraktowanych operacji i wartości zrealizowanych płatności. Analiza danych zawartych w tabeli 1 i tabeli 2 skłania do wniosku, że konieczne jest przyspieszenie tempa zawierania umów i wydawania decyzji. 


\section{Literatura}

BGK. Dane liczbowe Funduszu Termomodernizacji i Remontów (Figures of Thermo-Modernisation and Renovation Fund). Pobrane w czerwcu 2016 z: https://www.bgk.pl/files/public/Pliki/Samorzady/ Dane_liczbowe_FTiR.pdf.

Chyłek, E.⿳亠幺. (2012). Biogospodarka w sektorze rolno-spożywczym (Bio-Economy in the Agriculture and Food Sector). Przemysł Spożywczy, 66, 32-35.

Efektywność energetyczna (Energy Efficiency). Pobrane w czerwcu 2016 z: http://www.mg.gov.pl/Energetyka/ Efektywnosc+energetyczna.

Gospodarz z energią (A Farmer with Energy). Pobrane w listopadzie 2017 z: http://www.gospodarzzenergia.pl/ raporty,wiesz-ile-energii-zuzywasz-,v9.

MRiRW. Monitoring i sprawozdawczość PROW 2007-2013 (Ministry of Agriculture and Rural Development, PROW 2007-2013 Monitoring and Reporting). Pobrane w listopadzie $2017 \mathrm{z}$ : http://www.minrol.gov.pl/ Wsparcie-rolnictwa/Program-Rozwoju-Obszarow-Wiejskich-2007-2013/Monitoring-i-sprawozdawczoscPROW-2007-2013/Zbiorcze-sprawozdania-biezace-z-realizacji-PROW-2007-2013.

MRiRW. Monitoring i sprawozdawczość PROW 2014-2020 (Ministry of Agriculture and Rural Development, PROW 2014-2020 Monitoring and Reporting). Pobrane w listopadzie $2017 \mathrm{z}$ : http://www.minrol.gov.pl/ Wsparcie-rolnictwa/Program-Rozwoju-Obszarow-Wiejskich-2014-2020/Monitoring-i-sprawozdawczoscPROW-2014-2020.

Program Rozwoju Obszarów Wiejskich (PROW) (The Rural Development Programme) 231-235. Pobrane w czerwcu 2016 z: http://www.minrol.gov.pl/Wsparcie-rolnictwa/Program-Rozwoju-Obszarow-Wiejskich2014-2020.

Rozporządzenie Ministra Rolnictwa i Rozwoju Wsi w sprawie szczegółowych warunków i trybu przyznawania oraz wypłaty pomocy finansowej na operacje typu „Modernizacja gospodarstw rolnych” w ramach poddziałania „Wsparcie inwestycji w gospodarstwach rolnych” objętego Programem Rozwoju Obszarów Wiejskich na lata 2014-2020 z dnia 21 sierpnia 2015 r. (Regulation of the Minister of Agriculture and Rural Development on detailed conditions and procedures of granting and pay-out of financial assistance for operations like "Agricultural Farms Modernisation" within the framework of sub-action "Support for Investments in Agricultural Farms" covered by the Rural Development Programme in the years 2014-2020 of $21^{\text {st }}$ August 2015). Dz.U. 2015, poz. 1371

Ustawa z dnia 18 grudnia 1998 r. o wspieraniu przedsięwzięć termomodernizacyjnych (The Act of 18th December 1998 on the Support for Thermo-Modernisation Projects). Dz.U. 1998, nr 162, poz. 1121, z późn. zm.

Ustawa z dnia 20 lutego 2015 r. o wspieraniu rozwoju obszarów wiejskich z udziałem środków Europejskiego Funduszu Rolnego na rzecz Rozwoju Obszarów Wiejskich w ramach Programu Rozwoju Obszarów Wiejskich na lata 2014-2020 (The Act of 20th February 2015 on rural development support co-financed with the European Agricultural Fund for Rural Development within the Rural Development Programme in the years 2014-2020). Dz.U. 2015, poz. 349

Ustawa z dnia 21 listopada 2008 r. o wspieraniu termomodernizacji i remontów (The Act of 21st November 2008 on the Support for Thermo-Modernisation and Renovation). Dz.U. 2008, nr 223, poz. 1459.

Ustawa z dnia 23 kwietnia 1964 r. Kodeks cywilny (The Act of 23rd April 1964. Civil Code). Dz.U. 2016, poz. 380,585 t.j.

Żmija, D. (2014). Zrównoważony rozwój rolnictwa i obszarów wiejskich w Polsce (Sustainable Development of Agriculture and Rural Areas in Poland). Studia Ekonomiczne, Uniwersytet Ekonomiczny w Katowicach, 166, 149-158.

Do cytowania / For citation:

Huterska A., Łapińska J., Zdunek-Rosa E. (2018). Zasady wykorzystania środków z Programu Rozwoju Obszarów Wiejskich na lata 2014-2020 do termomodernizacji gospodarstw rolnych. Problemy Rolnictwa Światowego, 18(1), 58-65; DOI: 10.22630/PRS.2018.18.1.5

Herda-Kopańska J. (2018). Rules of Using Rural Development Programme Funds for the Years 2014-2020 for Thermo-Modernisation of Agricultural Farms (in Polish). Problems of World Agriculture, 18(1), 58-65; DOI: 10.22630/PRS.2018.18.1.5 